CHUNG-YING CHENG

\title{
INTRODUCTION: \\ CHINESE PHILOSOPHY IN EXCAVATED EARLY TEXTS
}

In 1973, Boshu Yijing yu Laozi《帛書易經與老子》 were excavated in Mawangdui. In 1993, Zhushu Zaoqi Rujia Zhuzuo 《竹書早期儒家著作》were unearthed in Guodian. Recently, more zhushu 竹書 were discovered, which are known as Qinghuajian 《清華簡》. In 1997, a group of excavated texts in bamboo inscriptions were bought by the Shanghai Metropolitan Museum and thus has become known as 《上海竹书》. These newly discovered texts aroused a great deal of enthusiasm among many Chinese and Western scholars in pursuing information, knowledge and wisdom from ancient Chinese tradition of Confucianism and Daoism as if those philosophers of ancient time have come back to life all at a sudden from the underground to enlighten us. For myself I started early with my intense interest in the Boshu Yijing and then gradually turned to the Guodian and Shanbo 上博 manuscripts of Daoism and Confucianism. What I have been interested are the philosophical significances of those texts in regard to issues of Chinese concepts of cosmic being and becoming, human self-being and human self-transformation, knowing, understanding, moral thinking and moral action. Specifically, the way those concepts are formed and developed suggested to me a methodology of growing and transformation from some notion of origin, source and root to a full-bodied concretized or concrete reality in a process of interaction, differentiation and integration, which I come to describes as "onto-genetic" or "onto-generative" (ben-ti). This no doubt is related to early my onto-hermeneutical thinking. In a period from 2004 to 2009 I have explored intermittently questions of onto-hermeneutic interpretation in early and contemporary Chinese Philosophy In light of excavated texts such as “taiyi sheng shui 太一生水," philosophical reasons why Xunzi objects to and criticizes Wu Xing theory attributed to Zisi and Mencius, and whether we may understand the theory of nature-emotion (xing-qing) as implying an onto-generative integration of Zisi, Mencius and Xunzi.

CHUNG-YING CHENG, Professor, Department of Philosophy, University of Hawaii at Manoa. Specialties: Confucianism and Neo-Confucianism, hermeneutics/ontohermeneutics, philosophy of language. E-mail: ccheng@hawaii.edu

Journal of Chinese Philosophy, Supplement to Volume 37 (2010) 1-5

(C) 2010 Journal of Chinese Philosophy 
The above anticipations motivated my goal of developing a special theme on the philosophical studies of these excavated materials. I cordially invited Professor Franklin Perkins of DePaul University, who shared the common thoughts and enthusiasm, to coedit the present Supplement issue.

What are the broad significance and value of these underground texts dated back to 300-350 BCE? Obviously, these underground texts are tremendously significant and valuable, because they represent and indicate a genuine part of ancient history with the mark of intelligence and insight of human being, and this should make us wonder how we are related to them and in what way they have actually contributed to what we know today. Hence to know the texts from the past is to know humanity at the present. In this sense we could be informed about the times and sometimes events under which these ancient texts were formed.

For instance, the discovery of Qinghuajian, which deals with questions of transferring or succeeding political rule as recorded in the Chinese Classic Shangshu 《尚書》or Shiji 《史記》(Book of History), could indicate or add weight to the belief that the Xia 夏 Dynasty was not just a historical legend but a culture with legitimate rule in a time earlier than either Shang 商 or Zhou 周. However, the significance and value of these excavated texts are far beyond historical and cultural considerations.

Such canonic materials present themselves as human thoughts composing of analytical distinctions and empirical observations with well-considered evaluations in either explicit arguments or hidden ones. In this sense they address to us as philosophical dialogues and dialectical explorations, showing a process of inquiry and a way of thinking. As we have examples of philosophical thinking and definitions in major classics of Daoism and Confucianism, we have come to a vivid representation and detailed delineation of meaning and use of words and terms, often ending in highly insightful propositions that explain and sometimes illuminate texts we know in our received tradition. They show versions or texts of differences and variations because of local innovations or renovations.

It is always intriguing to raise question as to whether there is a standard text in the beginning or how a plurality comes to exist after a paradigm left a cluster of expositions. In the case of the Yijing 《易經》(the Book of Changes) there could be a standard proto-type text in use for thousand years, but the same system of symbols could be arranged in different ways because of multiple orderings of numbers. But for the Confucian tradition the teaching of Confucius could result in division of schools and excavated texts such as “Wu Xing”〈五行〉 and “Xing Zi Ming Chu”〈性自命出〉 (XZMC 
henceforth) could represent ontological and analytical explorations that end in the formation of other classical texts such as Zhong Yong 《中庸》 and Daxue 《大學》. This type of similar variations in method or representation may apply to the case of excavated Daoist texts like Daodejing 《道德經》A and B as well, but we witness here far more accord and unison of representation than in Confucian texts. By and large, these texts Daoist or Confucian disclose how disciples of Confucius or believers of Laozi are truly inspired followers of the dao. They together make ancient Chinese indisputably a people of philosophy par excellence. Philosophy here means wisdom of care as well as love of wisdom.

One singularly important issue concerns how we come to have virtuous actions (de zhi xing 德之行) as exemplified in actions of ren, $y i, l i, z h i$, or xin as taught by Confucius. The acumen of this question lies in that we can describe these actions of virtue as simply actions not necessarily having anything to do with virtue. The question therefore reduces to where virtues come from, from an internal process of impulse in mind or from compliance with an external standard? It is in fact a question derived from the inner tension between $l i$ and $r e n$ in the Confucius' thinking. As Confucius speaks of unity of the dao of his thought, what would be a Confucian answer?

The Boshu and Guodian texts on Wu Xing or five virtues lead us to think that virtues must bear a mark of their own as derived from human mind or human nature. It leads us to think that those moral principles must be shared by all men so that our actions based on them will not only be called good but morally virtuous. The question of internal ontogenesis of virtues is the first query into moral psychology that would have to lead to the question of the ultimate origin of human nature or humanity.

How does question of an internal origination of virtues lead to a theory of human nature is extremely interesting as it marks a great difference of Chinese or Confucian philosophy from Greek philosophy. Whereas Socrates and Plato could take human minds as taking copies from Platonic ideas and thus satisfying the question of origin, the Chinese or Chinese seekers have to reflect and speculate on how human beings become human beings as a whole body, not just as minds. This is, the Confucian has to take feelings and emotions of humanity seriously and observes them to be constituents of virtues that are eventually shared by all people. Hence they come to take the common way of wisdom and virtue in human interactions as derived from and reflected in human feelings. This is the statement of "Dao sheng yu qing 道生於情" in the excavated text of XZMC. What is to be taken in mind is the vividness of the lived-through quality of deep experience of the thinker, and it is not a state of pure speculation but 
an articulation of vision and embodiment of the vision in the individual philosophical thought of the author(s) as the thinker(s).

There are two more instances as to how these excavated texts appeal to our own observations and reflections on things of history and nature. On the history side the excavated texts of Rongchengshi 容成氏 and Tangyuzhidao 唐虞之道 seem to indicate a utopia in the imagined past of antiquity, reflecting a state of both criticism and aspiration of the times during the Warring States Period. However, the authors of these texts who present the case of succession of sagely yielding (shan rang 禪讓) need not to be simply treated as utopian dreamers of the early Daoists, rather, they can be seen as suggesting a different way of conceiving the rise of human society and political government.

For we could well imagine that in an early ecology of abundance of life supplies, people needs a ruler who would volunteer to organize people for resisting common foes or for solving problems because of natural disasters. The political leadership of a ruler is taxing but the ruler has to use it without selfish desires in order to be worthy of respect given to him by the people supporting him, and he must start as a talented person in the first place. This volunteer sage-king origin of government needs not to be a sheer figment of imagination, for we can see still selfless people today who did just the same and they did that because they can also enjoy doing it. This is different from and even in stark contrast with theories of origins of government as we find in Hobbes, Lock, and Rousseau.

Furthermore, I want to point out the text titled "Taiyi Sheng Shui 《太一生水》" as a sophiscated illustration of the Chinese cosmological and cosmogonic way of thinking. It is clear that taiyi is not the same as taiji that in the Yizhuan 《易傳》gives rise to a sequence of symbolic states of yin and yang combinations, which would stand for changes and transformations of both nature and human affairs. To speak of giving birth to water is highly Daoistic and Yijing-oriented. Why so? For the Daoists water is always a symbol of formless and abundance, and for the Yijing thinkers water would represent the states of change that spans the invisible vapor or $q i$ 氣 and the life that is nourished by water. The deeper aspect of this text is in the idea of “fanbu 反哺” feedback or "reverse nourishing."

That is, the very spirits of heaven and earth is with all life and human beings in a nourishing and "return nourishing" cycle. This is a cycle of life that would continue and sustain by itself. There is the implication that the universe is indeed a cosmos or a living harmony in the process of ceaseless generation, for what return nourishing has made possible is that there is no separation of the present from the past and the upper from the lower, all of which are mutually supported in an interdependent network. This image of the world at large 
is a world that Daoists and Yijing thinkers and diviners could embrace without disparagement, even though we may not have to use yin-yang symbols for showing how interactions have taken place. They have taken place in the simplest way, the nourishing and return nourishing way of water and things nourished by water. We may need this cosmic image for our environmental consciousness and our survival may depend on raising this consciousness.

It is clear that among the nine articles there are many highly significant topics presented and discussed by well-established specialists, philosophers and historians, of the fields. The formation of this volume is an arduous process because diverse approaches have to be introduced and appreciated to reconsider these fundamental issues of the Boshu and Zhujian in a philosophical manner. The multiple styles of writing have to be made in uniform and the quotations of the inscriptions have to be made congruous. This means that both writers and editors have to go through a tedious process of inquiring into the excavated texts many times and carefully weighing evidence and interpretation in balance. It is indeed a test of the method of ontohermeneutical methodology, which is a theory I have been advocating. To a large extent, it is in fact presupposed by many contributors in presenting their results in coherent and relevant reference.

But all these difficulties, linguistic, technical, or ideological, have to be overcome by our supporting team. First of all, Professor Franklin Perkins not only took part in the editorship, but more than that, he has been devoted to many painstaking labors of corresponding, translating/retranslating, revising, and copy-editing. I thank Frank for joining me in time and relieving me in need. Our Managing Editor Linyu Gu went over each paper many times and made sure each detail as perfect as possible. I thank her for her diligence, patience, and suggestions on behalf of all contributors. I was much boosted in spirit because of these colleagues in pushing the publication to reality, for without them I doubt whether we would have the present result at hand. As always, I thank On-cho Ng, our Associate Editor, for taking care of rights matters and other issues on my behalf in the final stage. We also would like to express our warm gratitude to Wiley-Blackwell's editors whose hard work made it possible to meet the tight publication schedule. Most of all, on behalf of the Journal, I deeply thank our contributors from both Mainland China and America. They took two solid years to make these fruitions, and their public spirits made their expertise available to our readers and other scholars, who are involved in a noble enterprise of envisioning and articulating the formation of early Chinese philosophy, whether Daoist, Confucian, or Yijing-ist. 